\title{
INFLUENCE OF ORGANIC SOLVENTS ON THE FURIN ACTIVITY
}

\author{
T. V. OSADCHUK ${ }^{1}$, O. V. SHYBYRYN ${ }^{1}$, A. V. SEMYROZ1, V. K. KIBIREV ${ }^{1,2}$ \\ ${ }^{1}$ Institute of Bioorganic Chemistry and Petrochemistry, \\ National Academy of Sciences of Ukraine, Kyiv; \\ ${ }^{2}$ Palladin Institute of Biochemistry, National Academy \\ of Sciences of Ukraine, Kyiv; \\ e-mail: osadchuk@bpci.kiev.ua
}

Furin belongs to a family of calcium-dependent serine proprotein convertases, which transform the inactive protein precursors into mature polypeptides. In model experiments, we studied the effect of organic solvents such as acetone, dimethyl sulfoxide (DMSO), dioxane, isopropanol and ethanol on the furin activity. Furin was found to retain up to $88 \%$ of its initial activity in the presence of DMSO, whereas in the presence of acetone only 30\%. Organic solvents formed the following decreasing sequence of their effects on furin: acetone $>$ isopropanol $>$ ethanol $>$ dioxane $>$ dimethyl sulfoxide. The relationship between the residual furin activity and solvent parameters such as relative polarity, dipole moment and $\log P$ were investigated. The effect of the organic solvent appeared not to correlate with any of the listed characteristics. Laidler-Scatchard's graphs, which according to a theory must be linear, demostrated non-linearity. These results indicate that not only electrostatic interactions play an important role in the studied enzymatic reaction but also other factors, e.g. hydrophobic contacts, hydrogen bonds can influence furin catalysis. This seems relevant for further research in this area.

K e y w o r d s: furin, organic solvents, furin activity, inhibition, activation.

$\mathrm{F}$ urin is a member of the $\mathrm{Ca}^{2+}$-dependent serine proprotein convertases (PCs) family, which is involved in the maturation of precursors in the secretory pathway. It transforms both soluble and membrane-bound proproteines into biologically active products: hormones, growth factors, receptors, enzymes, adhesion molecules, etc. [1-3]. In addition to normal physiological functions furin can participate in an array of different pathological states including cancer, various bacterial and viral infections, atherosclerosis, endocrinopathies, neurodegenerative diseases [4-6]. Therefore, furin is considered as an attractive target for the synthesis of specific inhibitors, which could find biochemical, clinical and therapeutic applications [3-6].

Furin is accumulated in the trans-Golgi network (TGN) and then recycles along TGN the cell membrane, and the endosomal compartmets [3], where it interacts with its protein substrates activating them. Since the polarity, $\mathrm{pH}$ values and ion concentration in cell compartments differ [7], we decided to study in the model experiments the effect of various components of the incubation medium (for example, metal ions, organic solvents, etc.) on furin.

In the literature, there are data on the effect of metal cations such as sodium and potassium [8-10], calcium and magnesium $[1,10]$, zinc, mercury and manganese [11] and other ions on the catalytic properties of furin. Previously, we also investigated the effect of some heavy metal ions: cesium, cobalt, and cadmium on the enzyme [12].

This report focused on the studying of the effect of some organic solvents added to the reaction medium on the furin catalytic activity. The influence of organic solvents on various enzymes has been studied in many laboratories [13-18], however there are no much relevant data on furin. Thus, it is crucial not only to create specific inhibitors of furin, but also to study the specific effects of various factors of the incubation medium on it. That can provide

(C) 2018 Osadchuk T. V. et al. This is an open-access article distributed under the terms of the Creative Commons Attribution License, which permits unrestricted use, distribution, and reproduction in any medium, provided the original author and source are credited. 
valuable information on the molecular mechanisms of furin action.

The purpose of our work was to carry out a comparative study of the effect of organic solvents on furin. To obtain data on the sensitivity and stability of the enzyme to the action of different solvents, we investigated their effect on the furin activity in the range of solvent concentrations from 0 to $30 \%$ $(\mathrm{v} / \mathrm{v})$.

Polar dimethyl sulfoxide (DMSO) is often used as a standard solvent for studying the effects of various synthetic and natural compounds on enzymatic processes. It is usually used to dissolve test compounds and then to screen them in model experiments. The addition of nonpolar dioxane to the incubation medium allows changing its dielectric constant in the wide range from about 80 to 2 . Ethanol and isopropanol, in addition to changing the permittivity, can compete with water in the acylenzyme cleavage stage, thereby inhibiting the enzymatic reaction.

\section{Materials and Methods}

Reagents and preparations. The following organic solvents were used: 1,4-dioxane, DMSO, acetone, ethanol and isopropanol (Sigma, USA). Commercial products were: EDTA (Serva, Germany), HEPES (Sigma, USA), $\beta$-mercaptoethanol, Triton (Fluka, Switzerland). The fluorogenic substrate Boc-Arg-Val-Arg-Arg-AMC was purchased from Bachem (Switzerland), and the shorter recombinant human furin (2000 U/ml) was purchased from New England BioLabs (USA). The amount of enzyme that under standard conditions cleaves 1 pmol of 7-amino-4-methylcoumarin (AMC) from the fluorogenic substrate per min was taken as the unit of furin activity. Before work, the solution of the commercial preparation of the enzyme was diluted 20-fold with a working HEPES buffer ( $\mathrm{pH}$ 7.3) and the resulting solution was used to carry out the enzymatic reaction.

The dielectric constant $\varepsilon$ of the incubation medium was calculated from the formula:

$$
\varepsilon=\left[\left(\varepsilon^{\prime}-\varepsilon_{0}\right) / 100\right] \mathrm{d},
$$

where $\varepsilon^{\prime}$ and $\varepsilon_{0}$ - are the dielectric permittivity of the organic solvents and water, respectively, $\mathrm{d}-$ is the percentage of these organic solvents in the reaction medium $[19,20]$. The magnitudes of the dielectric constants of water $\left(\varepsilon_{0}\right)$ and organic solvents $\left(\varepsilon^{\prime}\right)$ at the temperature of the incubation medium were calculated using the values of the temperature coefficients of their permittivity: water $\left(-4.63 \cdot 10^{-3}\right)$, ethanol $\left(-6.02 \cdot 10^{-3}\right)$, acetone $\left(-4.63 \cdot 10^{-3}\right)$, dioxane $\left(-0.77 \cdot 10^{-3} \mathrm{~K}^{-1}\right)[19,20]$, or using the published data on the dependence of the permittivity on temperature [22-27].

The inhibition coefficients of furin activity were calculated by the formula:

$$
\mathrm{A}=\left(V_{0}-V\right) / V_{0},
$$

where $V_{0}$ - is the initial maximum rate of the enzymatic reaction, and $V$ - is the maximum reaction rate in the presence of an organic solvent in the incubation medium.

Determination of furin activity. An aliquot of the furin solution, containing 1 unit of the enzyme activity was incubated in $\mathrm{pH} 7.3$ buffer $(100 \mathrm{mM}$ HEPES, $1 \mathrm{mM} \mathrm{CaCl}_{2}, 0.5 \%$ Triton X-100 and $1 \mathrm{mM}$ $\beta$-mercaptoethanol) for $1 \mathrm{~h}$ at $37^{\circ} \mathrm{C}$ with fluorogenic substrate $(75-250 \mu \mathrm{M})$ in a $150 \mu 1$ sample. The reaction was terminated by adding $2 \mathrm{ml}$ EDTA (initial concentration $5 \mathrm{mM}$ ) and the relative fluorescence was measured on a PTI Quanta Master 40 spectrofluorometer (Canada) at an excitation wavelength of $380 \mathrm{~nm}$ and an emission of $460 \mathrm{~nm}$. The fluorescence readings were recorded for $60 \mathrm{sec}$. The values of the Michaelis constants were determined by plotting the Lineweaver-Burk graphs in three independent experiments.

Determination of the influence of organic solvents on furin. The concentrations of organic solvents in the mixture with buffer ranged from 0 to $30 \%(\mathrm{v} / \mathrm{v})$. The furin solution $(10 \mu \mathrm{l})$ containing 1 unit of enzyme activity, the required amount of organic solvent and $10 \mu \mathrm{l}$ of the fluorogenic substrate were successively added to HEPES buffer (total volume of the sample was $150 \mu \mathrm{l}$ ). The reaction was terminated by adding $2 \mathrm{ml}$ EDTA, and further processing of the samples was conducted as described above. The fluorescence values for the mixtures which did not contain organic solvents, were taken as $100 \%$

\section{Results and Discussion}

In the presence of organic solvents, enzymes usually, undergo denaturation and inactivation $[13,14]$. This is due to, for example, changes in $\mathrm{pK}$ values of acidic and basic groups not only of the active center or surface of the enzyme, but also dissociating groups of buffer solutions [13].

Organic solvents can affect not only the stability and activity of enzymes but also change their 
specificity [13]. To date, examples of proteinases resistant to the action of organic solvents are well known [15-18].

To obtain data on the furin stability and sensitivity to various solvents, we tested following organic solvents: acetone (aprotic polar solvent), 1,4-dioxane (aprotic nonpolar solvent), ethanol and isopropanol (proton-containing polar solvents). Their effects on furin activity are shown in Fig. 1.

It is seen that the effect of the solvent depends on its chemical nature. Thus, the presence of dioxane (5\%) or isopropanol (10\%) in the incubation medium caused an increase in the enzyme activity by about $30 \%$ and $60 \%$, respectively. A further increase in the concentration of these solvents led to a dose-dependent decrease in the furin activity. In the presence of ethyl alcohol or acetone (concentration 10\%), there was practically no increase in the enzyme activity, but an increase in the solvent concentration in the reaction medium was found to inhibit furin activity. Acetone appeared to exibit the greatest inhibitory effect on the enzyme. Thus, at concentration of $25 \%$ a decrease in the initial enzyme activity by $70 \%$ was observed. The least effect on furin was observed in the presence of DMSO: furin remained active ( $\sim 88 \%)$ at the solvent concentration up to $\sim 25 \%$. Thus, among the studied solvents, DMSO was found to be the best solvent in terms of furin stability. The tested organic solvents (at a concentration of 25\%) can be arranged in the descending order of their effect on the enzyme: acetone $>$ isopropanol $>$ ethanol $>$ dioxane $>$ DMSO.

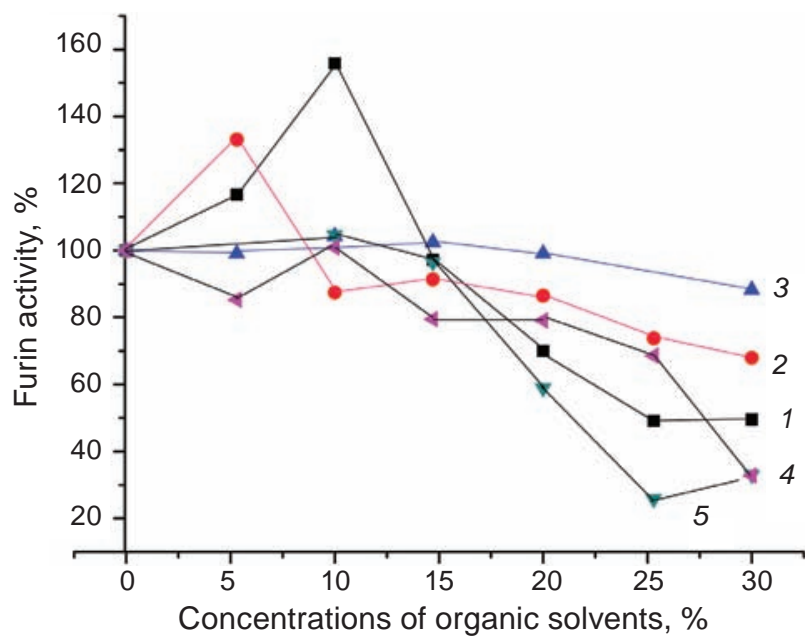

Fig. 1. The effect of organic solvents on furin activity at $\mathrm{pH}$ 7.3: 1 - isopropanol, 2 - dioxane, 3 -dimethyl sulfoxide, 4-ethanol, 5 - acetone
The important physico-chemical characteristics of organic solvents are known to be dielectric permeability, polarity and hydrophobicity. Thus, the influence of the solvent on the chemical reaction is determined by its donor-acceptor properties and dielectric permittivity [13].

We studied how the enzyme activity changed (at a solvent concentration of $25 \%$ in the incubation medium) depending on the following characteristics of the solvents: dipole moment, the calculated $\log P$ value, and relative polarity. These characteristics were found on the Internet and are given in Table 1.

The inhibitory effect of the studied solvents was found to not correlate with any of the above characteristics, although the best approximation to the linear dependence was observed for the solvent relative polarity values (Fig. 2).

In this graph, the two points corresponding to dioxane and DMSO were outside the straight line.

According to the theory [21], Laidler-Scatchard's plots reflecting the dependence of the enzymatic reaction efficiency $(\ln A)$ on the dielectric constant of the medium $(1 / \varepsilon)$ must be linear. To make sure, we decided to construct an appropriate graph for furin. Using the initial data (Table 2), the values of the dielectric permittivity of buffer-solvents mixtures ( $\mathrm{pH}$ 7.3) were calculated (see the Materials and Methods section) at their concentrations $0,5,10,15$, 20, 25 and 30\%, and changes in the furin activity depending on $1 / \varepsilon$ of the incubation medium were traced (Fig. 3).

Fig. 3 shows the corresponding plots in the Laidler-Scatchard's coordinates.

The presented plots show a non-linear dependence, and the greatest deviations from linearity were observed at sites corresponding to an or-

Ta b le 1. Parameters of used organic solvents

\begin{tabular}{l|c|c|c}
\hline \multicolumn{1}{c|}{ Solvent } & $\begin{array}{c}\text { Relative } \\
\text { polarity }\end{array}$ & $\begin{array}{c}\text { The dipole } \\
\text { moment } \\
(\mu), \text { Debye }\end{array}$ & $* \log P$ \\
\hline $\begin{array}{l}\text { Buffer without } \\
\text { organic solvent }\end{array}$ & 1.000 & 2.88 & \\
DMSO & 0.444 & 3.96 & -1.35 \\
Dioxane & 0.164 & 0.45 & 0.46 \\
Ethanol & 0.654 & 1.69 & -0.32 \\
Isopropanol & 0.546 & 3.96 & 0.14 \\
Acetone & 0.355 & 2.88 & -0.24 \\
\hline
\end{tabular}

Notes: *the calculated values of $\log P$ are presented 


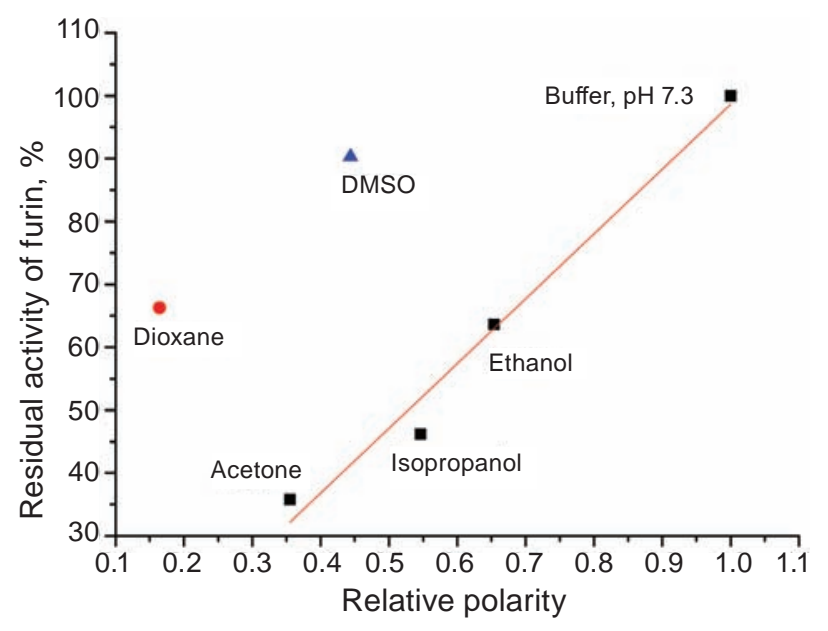

Fig. 2. Dependence of the furin activity on the relative polarity of the investigated solvents

ganic solvent concentration of $0-15 \%$. When ethyl alcohol was used at concentration $0-20 \%$ the linear dependence of the Laidler-Scatchard graph was realized in this part of the curve (Fig. 3, B, 2). For isopropanol and dioxane (Fig. 3, A, 1 and 2), as well as for acetone (Fig. 3, B, 3), the rectilinear section corresponds to the solvent concentration range of $15-30 \%$. When using DMSO, there is no linear dependence on the Laidler-Scatchard graph (Fig. 3, B, 1). These features of the plots may indicate that in catalysis by furin, an important role play not only electrostatic interactions, but other factors such as hydrophobic contacts and hydrogen bonds between the enzyme binding site and the substrate/inhibitor also have significant values for reaction [13]. The

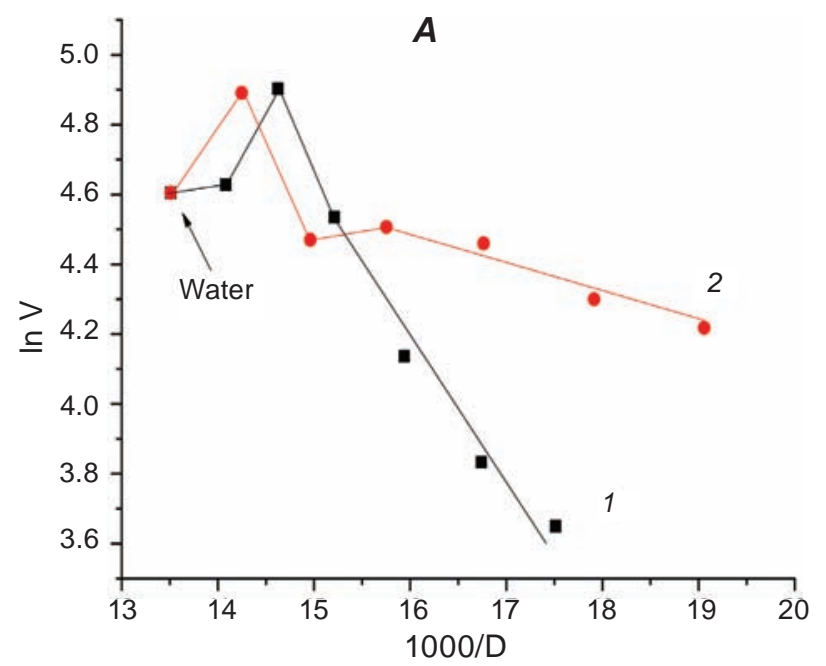

Table 2. The calculated values of the solvents permittivity at $37^{\circ} \mathrm{C}$

\begin{tabular}{l|c|c}
\hline \multicolumn{1}{c|}{ Solvent } & $\begin{array}{c}\text { Calculated } \\
\text { dielectric } \\
\text { permittivity, } \varepsilon\end{array}$ & $\begin{array}{c}\text { Sources } \\
\text { of information }\end{array}$ \\
\hline Acetone & 18.08 & {$[23]$} \\
DMSO & 46.01 & {$[24,26]$} \\
1,4-Dioxane & 2.19 & {$[22]$} \\
Isopropanol & 17.62 & {$[27]$} \\
Ethanol & 22.59 & {$[23]$} \\
Water & 74.19 & {$[25]$} \\
\hline
\end{tabular}

viscosity of the medium or its ionic strength, etc., can also be of great importance for catalysis [13]. To assess their contribution to the enzymatic reaction, further study is needed.

Thus, in the model experiments we showed the effect of some organic solvents on the functional activity of furin. These solvents can be arranged, depending on the impact, in the following sequence - from the most aggressive to the most tolerant: acetone $>$ isopropanol $>$ ethanol $>$ dioxane $>$ dimethyl sulfoxide. The obtained Laidler-Scatchard graphs reflecting the dependence of the efficiency of the enzymatic reaction on the medium dielectric constant $(\ln \mathrm{A}-1 / \varepsilon)$, as well as the dependences of the furin activity on the dipole moment, the calculated $\log P$ value, and the solvent relative polarity appeared to be a non-linear. Thus, the effectiveness of the enzymatic reaction is most likely determined

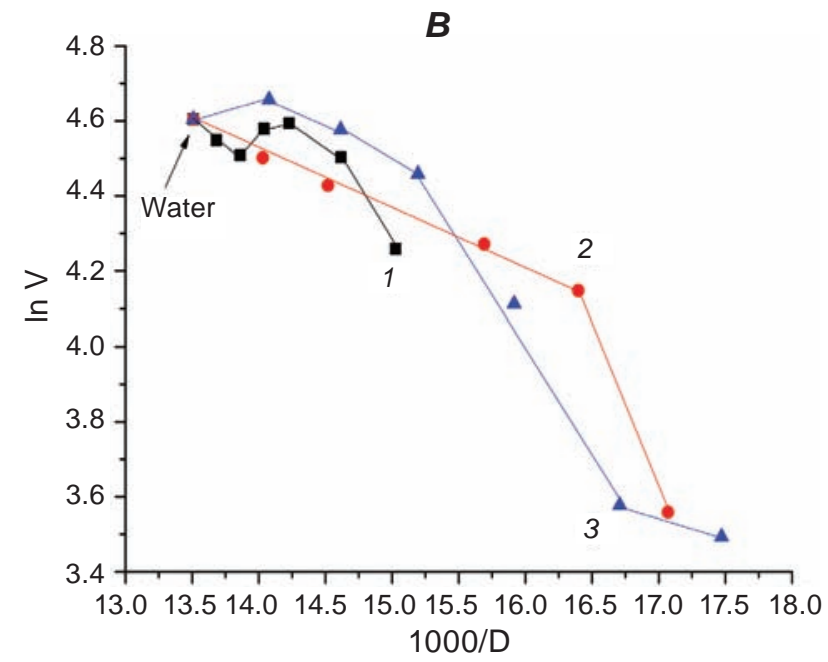

Fig. 3. Influence of the dielectric constant of the reaction medium on the furin activity. A: 1 - Isopropanol, 2 - Dioxane; B: 1 - Dimethyl sulfoxide, 2 - Ethanol, 3 - Acetone 
by not only electrostatic interactions of the reagents but also other factors: hydrophobic contacts, hydrogen bonds, etc. These results are relevant for further research in the field.

\section{ВПЛИВ ОРГАНІЧНИХ РОЗЧИННИКІВ НА АКТИВНІСТЬ ФУРИНУ}

\author{
T. В. Осадчук ${ }^{1}$ О. В. Шибирин ${ }^{1}$, \\ А. В. Семироз ${ }^{1}$, В. К. Кібірєв ${ }^{1,2}$ \\ ${ }^{1}$ Інститут біоорганічної хімії \\ та нафтохімії НАН України, Київ; \\ ${ }^{2}$ Інститут біохімії ім. О. В. Палладіна \\ НАН України, Київ; \\ e-mail: osadchuk@bpci.kiev.ua
}

Фурин належить до сімейства кальційзалежних серинових пропротеїнконвертаз, які здійснюють перетворення неактивних прекурсорів протеїнів в зрілі поліпептиди. У модельних експериментах ми вивчили вплив на активність ензиму таких органічних розчинників, як ацетон, диметилсульфоксид (ДМСО), діоксан, ізопропанол і етанол. Знайдено, що в присутності ДМСО фурин зберігав свою вихідну активність до $88 \%$, тоді як за наявності ацетону - всього лише до $30 \%$. Встановлено таку послідовність зниження впливу органічних розчинників на фурин: ацетон> ізопропанол> етанол> діоксан> диметилсульфоксид. Досліджено взаємозв'язок між залишковою активністю фурину і такими параметрами розчинника, як діелектрична проникність, відносна полярність, дипольний момент i $\log P$. Виявилося, що величина ефекту органічного розчинника не корелює ні з однією з наведених характеристик. Графіки в координатах Лейдлера-Скетчарда, які відповідно до теорії, мають бути лінійними, не є такими. Все це свідчить про те, що в розглянутій ензимній реакції важливу роль відіграють не тільки електростатичні взаємодії, але і гідрофобні контакти, водневі зв'язки та інші фактори також можуть впливати на каталіз фурином. Це видається актуальним для подальших досліджень у зазначеній області.

Ключов і слова: фурин, органічні розчинники, активність фурину, інгібування, активація.

\section{ВЛИЯНИЕ ОРГАНИЧЕСКИХ РАСТВОРИТЕЛЕЙ НА АКТИВНОСТЬ ФУРИНА}

T. В. Осадчук ${ }^{1}$ Е. В. Шибирин ${ }^{1}$, А. В. Семироз ${ }^{1}$, В. К. Кибирев ${ }^{1,2}$

${ }^{1}$ Институт биоорганической химии и нефтехимии НАН Украины, Киев;

${ }^{2}$ Институт биохимии им. А. В. Палладина НАН Украины, Киев; e-mail: osadchuk@bpci.kiev.ua

Фурин относится к семейству кальций-зависимых сериновых пропротеинконвертаз, осуществляющих превращение неактивных прекурсоров протеинов в зрелые полипептиды. В модельных экспериментах мы изучили влияние на активность энзима таких органических растворителей, как ацетон, диметилсульфоксид (ДМСО), диоксан, изопропанол и этанол. Показано, что в присутствии ДМСО фурин сохранял свою исходную активность до $88 \%$, тогда как при наличии ацетона - всего лишь до $30 \%$. Установлена следующая последовательность снижения влияния органических растворителей на фурин: ацетон $>$ изопропанол $>$ этанол $>$ диоксан $>$ диметилсульфоксид. Исследована взаимосвязь между остаточной активностью фурина и такими параметрами растворителя, как диэлектрическая проницаемость, относительная полярность, дипольный момент и $\log P$. Оказалось, что величина эффекта органического растворителя не коррелирует ни с одной из приведенных характеристик. Графики в координатах Лейдлера-Скетчарда, которые согласно теории должны быть линейными, не являются таковыми. Все это свидетельствует о том, что в рассматриваемой энзимной реакции важную роль играют не только электростатические взаимодействия, но и гидрофобные контакты, водородные связи и другие факторы также могут влиять на катализ фурином. Это представляется актуальным для дальнейших исследований в данной области.

К лю че вы е с лов а фурин, органические растворители, активность фурина, ингибирование, активация. 


\section{References}

1. Molloy SS, Bresnahan PA, Leppla SH, Klimpel KR, Thomas G. Human furin is a calciumdependent serine endoprotease that recognizes the sequence Arg-X-X-Arg and efficiently cleaves anthrax toxin protective antigen. $J$ Biol Chem. 1992; 267(23): 16396-16402.

2. Hosaka M, Nagahama M, Kim WS, Watanabe T, Hatsuzawa K, Ikemizu J, Murakami K, Nakayama K. Arg-X-Lys/Arg-Arg motif as a signal for precursor cleavage catalyzed by furin within the constitutive secretory pathway. J Biol Chem. 1991; 266(19): 12127-12130.

3. Thomas G. Furin at the cutting edge: from protein traffic to embryogenesis and disease. Nat Rev Mol Cell Biol. 2002; 3(10): 753-766.

4. Artenstein AW, Opal SM. Proprotein convertases in health and disease. $N$ Engl J Med. 2011; 365(26): 2507-2518.

5. Seidah NG, Prat A. The biology and therapeutic targeting of the proprotein convertases. Nat Rev Drug Discov. 2012; 11(5): 367-383.

6. Couture F, Kwiatkowska A, Dory YL, Day R. Therapeutic uses of furin and its inhibitors: a patent review. Expert Opin Ther Pat. 2015; 25(4): 379-396.

7. Casey JR, Grinstein S, Orlowski J. Sensors and regulators of intracellular pH. Nat Rev Mol Cell Biol. 2010; 11(1): 50-61.

8. Izidoro MA, Gouvea IE, Santos JA, Assis DM, Oliveira V, Judice WA, Juliano MA, Lindberg I, Juliano L. A study of human furin specificity using synthetic peptides derived from natural substrates, and effects of potassium ions. Arch Biochem Biophys. 2009; 487(2): 105-114.

9. Rockwell NC, Fuller RS. Specific modulation of Kex2/furin family proteases by potassium. $J$ Biol Chem. 2002; 277(20): 17531-17537.

10. Izidoro MA, Assis DM, Oliveira V, Santos JA, Juliano MA, Lindberg I, Juliano L. Effects of magnesium ions on recombinant human furin: selective activation of hydrolytic activity upon substrates derived from virus envelope glycoprotein. Biol Chem. 2010; 391(9): 1105-1112.

11. Podsiadlo P, Komiyama T, Fuller RS, Blum O. Furin inhibition by compounds of copper and zinc. J Biol Chem. 2004; 279(35): 36219-36227.

12. Osadchuk TV, Shybyryn OV, Semyroz AV, Bondarenko OM, Kibirev VK. Influence of cations on furin activity. Ukr Biochem J. 2017; 89(5): 15-20.
13. Webb JL. Enzyme and metabolic inhibitors. M.: Mir, 1966, 862 p. (In Russian).

14. Gupta MN. Enzyme function in organic solvents. Eur J Biochem. 1992; 203(1-2): 25-32.

15. Doukyu N, Ogino H. Organic solvent-tolerant enzymes. Biochem Eng J. 2010; 48(3): 270-282.

16. Hemke VM, Dhundale VR. Effect of organic solvents on the activity and stability of an extracellular protease secreted by the haloalkaliphilic Bacillus firmus HS4. Int $J$ Pure App Biosci. 2017; 5(4): 1980-1988.

17. Badoei-Dalfard A, Karami Z. Screening and isolation of an organic solvent tolerant protease from Bacillus sp. JER02: Activity optimization by response surface methodology. J Mol Catal B: Enzymatic. 2013; 89(2): 15-23.

18. Anbu P. Enhanced production and organic solvent stability of a protease from Brevibacillus laterosporus strain PAP04. Braz J Med Biol Res. 2016; 49(4): e5178.

19. Kosterin SA, Bratkova NF, Slinchenko NN, Zimina VP. Effect of organic solvents on catalytic and functional activity of transport $\mathrm{Ca}^{2+}, \mathrm{Mg}^{2+}-$ ATPase from smooth muscle cell membrane. Biofizika. 1998; 43(6): 1037-1042. (In Russian).

20. Moelwyn-Huges EA. Physical chemistry. Book 2, Foreign Literature Publishing House M, 1962. 1148 p. (In Russian).

21. Laidler KJ. The chemical kinetics of enzyme action. London, Oxford University Press, 1958. $420 \mathrm{p}$.

22. Critchfield FE, Gibson JA, Hall JL. Dielectric constant for dioxane-water system from 20 to 35. J Am Chem Soc. 1953; 75(8): 1991-1992.

23. Akerlof G. Dielectric constants of some organicwater mixtures at various temperatures. $J \mathrm{Am}$ Chem Soc. 1932; 54(11): 4125-4139.

24. Bhat JI, Manjunatha MN. Studies on the effect of dielectric constant on the salvation behavior of citric acid as a function of temperature. Arch Appl Sci Res. 2011; 3(5): 362-380.

25. Malmberg CG, Maryott AA. Dielectric constant of water from $0^{\circ}$ to $100^{\circ}$ C. $J$ Res Nat Bureau Stand. 1956; 56(1): 1-7.

26. Gaylord Chemical Company, Sulfoxide Physical Properties, 2014, Bulletin 101.

27. Dortmund Data Bank Software Package, 2012, $122 \mathrm{p}$.

Received 27.04.2018 